\title{
EFEKTIFITAS MEDIA KOMPUTER DENGAN PERANGKAT LUNAK POWERPOINT DALAM MENINGKATKAN HASIL BELAJAR BAHASA INGGRIS MATERI PRONOUN PADA PESERTA DIDIK KELAS $X$ TEKNIK SURVEYING DI SMK NEGERI 3 GORONTALO TAHUN PELAJARAN 2018/2019
}

\author{
Maryam Jusuf ${ }^{1}$ \\ SMK Negeri 3 Gorontalo \\ jusufmaryam79@gmail.com
}

\begin{abstract}
ABSTRAK
Penelitian ini bertujuan untuk mengembangkan perangkat pembelajaran yang berbasis komputer dengan perangkat lunak PowerPoint yang diimplementasikan pada peserta didik kelas X program keahlian Teknik Surveying, dengan harapan dapat meningkatkan ketuntasan belajar Bahasa Inggris peserta didik pada materi Pronoun. Dari data pada siklus I menunjukkan : peserta didik memperoleh nilai kurang dari 75 sebanyak 15 peserta didik $(40,54 \%)$ dan rentang nilai lebih dari 75 sebanyak 22 peserta didik $(59,46 \%)$. Daya serap peserta didik mencapai $75,5 \%$. Aktifitas peserta didik dari 37 orang terdapat 21 peserta didik $(56,76 \%)$ termasuk sangat aktif dan aktif, dan 16 peserta didik $(43,24 \%)$ tergolong kategori kurang aktif dan tidak aktif. Pada siklus II dari 37 peserta didik diperoleh data nilai kurang dari 75 sebanyak 2 peserta didik $(5,41 \%)$ dan rentang nilai lebih dari 75 sebanyak 35 peserta didik (94,59\%). Daya serap peserta didik mencapai $81,49 \%$. Aktifitas peserta didik dari 37 orang terdapat 29 peserta didik $(78,38$ $\%)$ termasuk sangat aktif dan aktif , dan 8 peserta didik (21,62\%) termasuk kategori cukup aktif dan kurang aktif. Data pemanfaatan media dalam proses pembelajaran diperoleh bahwa semua peserta didik sangat tertarik dengan penggunaan media power point. Hal ini dapat dilihat bahwa $100 \%$ peserta didik menyatakan menyenangkan, 89,19 $\%$ menyatakan menerima pelajaran dengan mudah, $86,49 \%$ peserta didik menjadi lebih aktif, peserta didik sangat termotivasi sebanyak $75,68 \%$ dan $83,78 \%$ peserta didik menyatakan paham, peserta didik yang menyatakan jenuh dalam menerima pelajaran tidak ada, tetapi yang menyatakan tidak merasa bosan sebanyak 33 peserta didik $(89,19$ $\%)$. Tingkat kesungguhan peserta didik dalam memperhatikan materi pelajaran yang disampaikan dengan media pembelajaran sangat besar yaitu 75,68 \%, dalam meningkatkan prestasi belajar peserta didik yang menyatakan nilainya menjadi lebih bagus sebanyak 29 peserta didik (78,38 \%), meningkatkan semangat dalam belajar peserta didik menyatakan lebih giat belajar sebanyak 35 peserta didik $(94,59 \%)$. Dari data tersebut diperoleh kesimpulan bahwa pembelajaran dengan media perangkat lunak power point secara signifikan lebih baik jika dibandingkan dengan pembelajaran konvensional yang selama ini dilakukan..
\end{abstract}

Kata kunci: Media Pembelajaran, Perangkat Lunak, Power Point dan Hasil Belajar Siswa

\section{PENDAHULUAN}

Dalam Undang-Undang Nomor 20 Tahun 2003 tentang Sistem Pendidikan Nasional menyatakan bahwa pendidikan nasional berfungsi mengembangkan kemampuan dan membentuk watak serta peradaban bangsa yang bermartabat dalam rangka 
mencerdaskan kehidupan bangsa , bertujuan untuk berkembangnya potensi peserta didik agar menjadi manusia yang beriman dan bertakwa kepada Tuhan Yang Masa Esa, berakhlak mulia, sehat, berilmu, cakap, kreatif, mandiri, dan menjadi warga negara yang demokratis serta bertanggungjawab.

Pembangunan pendidikan nasional ke depan didasarkan pada paradigma membangun manusia Indonesia seutuhnya, yang berfungsi sebagai subyek yang memiliki kapasitas untuk mengaktualisasikan potensi dan dimensi kemanusiaan secara optimal. Dimensi kemanusiaan itu mencakup tigal hal paling mendasar, yaitu (1) efektif yang tercermin pada kualitas keimanan, ketakwaan, akhlak mulia termasuk budi pekerti luhur serta kepribadian unggul, dan kompetensi estetis; (2) kognitif yang tercermin pada kapasitas pikir dan daya intelektualitas untuk menggali dan mengembangkan serta menguasai ilmu pengetahuan dan teknologi; dan (3) psikomotorik yang tercermin pada kemampuan mengembangkan ketrampilan teknis , kecakapan praktis, dan kompetensi kinestetis.

Di dalam masyarakat berbasis pengetahuan, peranan ilmu pengetahuan dan teknologi sangat dominan. Masyarakat Indonesia yang Indeks teknologinya masih rendah belum secara optimal memanfaatkan iptek sebagai penggerak utama (prime mover) perubahan masyarakat. Pendidikan memfasilitasi peningkatan indeks teknologi tersebut, namun demikian, peningkatan indeks teknologi tidak semata-mata ditentukan oleh pendidikan , melainkan juga oleh transfer teknologi yang biasanya menyertai investasi. Penyertaan investasi memerlukan sumber daya manusia yang mampu mengejawantahkan nilai-nilai sosial kemasyarakatan.

Jika berbicara mengenai upaya peningkatan sumber daya manusia, tentu tidak terlepas dari peran lembaga dan sistem yang dilkasanakan, tak dapat dipungkiri pula bahwa peran media dan teknologi dalam pengajaran sangat diperlukan untuk meningkatkan kualitas pendidikan guna mencipakan masyarakat maju dan modern.

Salah satu ciri yang menunjukkan masyarakat maju dan modern adalah banyak orang yang hidupnya merupakan hasil rancangan dan rekayasa manusia itu sendiri. Selain itu juga bahwa yang menun-jukkan perubahan manusia dari keadaan tradisional menjadi manusia modern, terlihat dari rancangan peralatan yang digunakan manusia untuk meumudahkan manusia dalam aktifitasnya sehari-hari.

Era globalisasi dan era kominukasi saat ini ditandai banyaknya manusia yang memanfaatkan teknologi informasi yang berbasis komputer untuk memenuhi kebutuhan hidup manusia. Kemajuan teknologi komputer yang sangat cepat, dan didukung oleh kemajuan teknologi informasi dapat digunakan untuk memperbaiki proses belajar dengan cara memanfaatkan penggunaan komputer. Dengan menggunakan perangkat lunak komputer dapat digunakan untuk mempermudah dan mendapatkan hasil yang optimal dari suatu pekerjaan

\section{KAJIAN PUSTAKA}

\section{Media Pembelajaran}

Kata media berasal dari bahasa latin dan merupakan bentuk dari kata medium yang secara harfiah berarti perantara atau pengantar. Media adalah perantara atau pengantar pesan dari pengirim ke penerima (Sadiman ,1993:6). Sedangkan menurut Gagne dalam Sadiman (1993:6) menyatakan media adalah berbagai jenis koponen dalam lingkungan siswa yang dapat merangsangnya untuk belajar. Briggs (1970:8) berpendapat bahwa media adalah segala alat fisik yang dapat menyajikan pesan serta merangsang siswa untuk belajar.

Menurut Sudjana dan Ahmad Rivai (1989:1) mengatakan bahwa ada dua aspek yang paling menonjol dalam metodologi 
pengajaran yakni metode mengajar dan media pengajaran sebagai alat bantu mengajar. Pengertian media meliputi alat bantu guru dalam meng-ajar serta sarana pembawa pesan dari sumber belajar ke penerima pesan belajar (peserta didik) sehingga proses pembelajaran menjadi jelas, menarik, interaktif, efektif dan efisien serta dapat mengurangi pema-haman yang abstrak pada diri peserta didik(Dayton, 1985) dalam Aristo Rohadi (2003:8).

Menurut Rohadi (2003:9) media adalah segala sesuatu yang dapat menyalurkan informasi dari sumber informasi kepada penerima informasi yang sering digunakan dalam bidang komunikasi dan termasuk ke dalam media meliputi teaching Aids, AVA dan media belajar atau sering disebut juga alat peraga.

Mc. Lucan dalam Wibawa dan Farida Mukti (1992:7) mengatakan bahwa media itu adalah semua saluran pesan yang dapat digunakan sebagai alat komunikasi. Menurutnya, media adalah semua saluran pesan yang dapat digunakan sebagai sarana komunikasi dari seseorang ke orang lain yang tidak ada dihadapannya. Romiszowski, berpendapat bahwa media adalah pembawa pesan yang berasal dari sumber pesan ( yang dapat berupa orang atau benda) kepada penerima pesan. Dalam proses belajar mengajar penerima pesan itu adalah siswa.

Adapun menurut Sudjana dan Ahmad Rivai (1991:1-2) mengatakan bahwa Media pengajaran dapat mempertinggi proses belajar peserta didik dalam pengajaran yang pada gilirannya diharapkan dapat mempertinggi hasil belajar yang dicapainya. Ada beberapa alasan, mengapa media pengajaran dapat mempertinggi proses belajar peserta didik. Alasan pertama berkenaan dengan manfaat media pengajaran dalam proses belajar siswa antara lain (a) pengajaran akan lebih menarik perhatian peserta didik sehingga dapat menumbuhkan motivasi belajar, (b) bahan pengajaran akan lebih jelas maknanya sehingga dapat lebih dipahami oleh peserta didik dan memungkinkan mereka menguasai tujuan pengajaran lebih baik, (c) metode mengajar akan lebih bervariasi, tidak semata-mata komunikasi verbal melalui penuturan katakata oleh guru, sehingga peserta didik tidak bosan dan guru tidak kehabisan tenaga, apalagi bila guru mengajar secara paralel , (d) peserta didik lebih banyak melakukan kegiatan belajar, sebab tidak hanya mendengarkan uraian guru, tetapi juga aktivitas lain seperti mengamati, melakukan, mendemonstrasikan dan lain-lain.

Alasan kedua adalah berkenaan dengan taraf berfikir peserta didik. Taraf berfikir manusia mengikuti tahap perkembangan dimulai dari berfikir sederhana menuju ke berfikir kompleks. Penggunaan media pengajaran erat kaitannya dengan tahapan berfikir tersebut sebab melalui media pengajaran hal-hal yang abstrak dapat dikongkretkan, dan hal-hal yang kompleks dapat disederhanakan.

\section{Komputer dan Pembelajaran}

Komputer berasal dari bahasa latin Computare yang berarti menghitung. Karena luasnya bidang garapan komputer, menurut Setiawan (2003: 2-3) para ahli mendifinisikan sebagai berikut :

a) Menurut Hammacher, komputer adalah mesin penghitung elektronik yang cepat dan dapat menerima informasi input digital dan memprosesnya sesuai dengan program yang tersimpan di memorinya dan menghasilkan output informasi

b) Menurut Blissmer, komputer adalah suatu alat elektronik yang mampu melakukan tugas menerima input, memproses input sesuai dengan program , menyimpan perintahperintah dan hasil dari pengolahan dan menyediakan output dalam bentuk informasi 
c) Menurut Fouri, komputer adalah suatu alat pemroses data yang dapat melakukan perhitungan besar secara cepat termasuk perhitungan aritmatika dan operasi logika, tanpa campur tangan manusia.

d) Menurut Umar Hamalik, komputer adalah suatu alat yang dapat menerima informasi, melaksanakan prosedur pemrosesan terhadap informasi tersebut, dan menyediakan informasi tersebut sesuai dengan keinginan sipemakai (user)

Dari ke empat pendapat tersebut dapat dinyatakan bahwa komputer sangat tepat digunakan sebagai teknologi dalam pembelajaran, sebab komputer dapat memprogram , membuat data , menyimpan program yang telah dirancang dan perancangan animasi yang dapat membuat daya khayal dan imajinasi siswa yang dapat kita rancang dan diprogram dalam komputer.

Penggunaan komputer dalam pembelajaran pada saat ini lebih dikenal dengan pendekatan berbasis e-learning atau sering juga disebut IT atau ICT yang menurut Collis dan Juang (2003:12) pemanfaatan komputer dalam pembelajaran dapat dikategorikan menjadi dua , yaitu pemanfaatan komputer sebagai core technology (teknologi utama) dan pemanfaatan komputer sebagai complementary tecnologi ( teknologi pendukung ). Teknologi utama dalam sistem pembelajaran adalah interaksi antara peserta didik dengan guru atau nara sumber lainnya atau sesama peserta didik.

\section{Power Point}

Microsoft Office Power Point adalah sebuah program komputer untuk presentasi yang dikembangkan oleh Microsoft. Power Point digunakan dalam PC berbasis sistem operasi Microsoft Windows dan juga Apple Macintosh yang menggunakan sistem operasi Apple Mac OS, meskipun pada awalnya aplikasi ini berjalan di atas sistem operasi Xenix. Aplikasi ini sangat banyak digunakan, apalagi oleh kalangan perkantoran dan pebisnis, para pendidik, peserta didik, dan trainer untuk presentasi. Power Point dapat menyimpan presentasi dalam beberapa format, yakni sebagai berikut:

Operasi Dalam Power Point, seperti halnya perangkat lunak pengolah presentasi lainnya,objek teks, grafik, video, suara, dan objek-objek lainnya diposisikan dalam beberapa halaman individual yang disebut dengan "slide". Istilah slide dalam Power Point ini memiliki analogi yang sama dengan slide dalam proyektor biasa, yang telah kuno, akibat munculnya perangkat lunak komputer yang mampu mengolah presentasise macam Power Point dan Impress. Setiap slide dapat dicetak atau ditampilkan dalam layar dan dapat dinavigasikan melalui perintah dari si presenter. Slide juga dapat membentuk dasar webcast (sebuah siaran di World Wide Web)

Presentasi memiliki beberapa tujuan. Tujuan presentasi akan sangat menentukan bagaimana kita akan melakukan dan mendesain presentasi. Tujuan yang dimaksud adalah menginformasikan, meyakinkan, membujuk, menginspirasi, dan menghibur,

\section{Hasil Belajar}

Belajar adalah suatu proses aktif melalui suatu latihan yang berakibat pada perubahan tingkat laku yang menuju kepada tujuan untuk memperoleh hasil yang terbaik. Belajar adalah proses perubahan tingkah laku yang dinyatakan dalam bentuk penguasaan, penggunaan dan penilaian terhadap atau mengenai sikap dan nilai-nilai pengetahuan dan kecakapan dasar yang terlibat di dalam berbagai bidang studi, lebih luas lagi dalam berbagai aspek bidang kehidupan atau pengalaman yang terorganisir (Rusyan, 1994).

Belajar akan berjalan dengan baik apabila disertai dengan tujuan belajar, karena 
belajar itu merupakan suatu aktivitas yang dapat membawa perubahan tingkah laku bagi peserta didik. Dalam belajar tentu akan ditemukan hambatan-hambatan, hambatanhambatan tersebut datangnya bisa dari peserta didik, lingkungan sekolah yang tidak menyenangkan.

Menurut Rochman Natawija (1985) bahwa faktor lingkungan sekolah yang kurang menunjang proses belajar seperti kurang memadainya cara mengajar, sikap guru, kurikulum atau materi ayang akan dipelajari, perlengkapan belajar, sistem administrasi, waktu belajar, situasi di sekolah dan sebagainya. Guru adalah salah satu komponen manusiawi dalam proses belajar mengajar, oleh karena itu, guru diharapkan untuk secara terus menerus berupaya agar berhasil dalam mengajar seperti yang ditulis oleh Thomas F Staton (1986) agar berhasil, tiap-tiap kegiatan pengajaran harus merangkum enam langkah kegiatan pokok yaitu (1) motivasi belajar, (2) memelihara perhatian sepenuhnya, (3) memajukan kegiatan mental ,(4) menciptakan suatu bahan yang jelas dari bahan-bahan yang dipelajari, (5) mengembangkan pengertian tentang arti, penerapan praktis dari bahan yang disajikan dan (6) mengulang semua langkah agar semua tujuan tercapai.

Langkah-langkah tersebut diperkuat oleh pendapat Deporter, B dkk (2000) mengatakan bahwa pekerjaan membantu peserta didik belajar yaitu menciptakan lingkungan belajar, memotivasi peserta dan mengendalikan disiplin dan suasana belajar. Termasuk kegiatan ini antara lain menyediakan sumber belajar, merangsang kegiatan yang dilakukan pesertas didik, mengatur pengalokasian waktu, menyediakan tempat belajar, menyediakan peralatan mengajar dan mengatur pengelolaan kelas.

Berdasarkan uraian di atas dapat diambil kesimpulan bahwa hasil belajar adalah kemampuan atau kapabilitas yang dimiliki siswa setelah ia melakukan proses belajar yang ditunjukan oleh penguasa-an materi tertentu, yang dapat diketahui setelah guru melakukan pengujian dengan menggunakan test.

\section{Hipotesis Tindakan}

Diharapkan dengan menggunakan media komputer perangkat lunak Power Point dapat meningkatkan hasil belajar peserta didik pada setiap siklusnya. Penelitian tindakan kelas ini diharapkan dapat mencapai hasil yang ideal dari siklus ke siklus

\section{Indikator Kinerja}

1. Daya serap perseorangan

Untuk mata pelajaran Bahasa Inggris, seorang peserta didik dikatakan tuntas belajar apabila telah memperoleh nilai sekurangkurangnya 7,3 atau mencapai skor $73 \%$

2. Daya serap klasikal

Untuk mata pelajaran Bahasa Inggris, suatu kelas disebut telah tuntas belajar jika kelas tersebut telah mencapai $85 \%$ dari jumlah peserta didik di kelas tersebut, dan telah mencapai daya serap perseorangan $73 \%$.

\section{METODE PENELITIAN}

Penelitian ini dilkasanakan di SMK Negeri 3 Gorontalo selama 2 (dua) bulan, dimulai pada minggu pertama bulan September 2018 s.d. minggu ke empat bulan Oktober 2018. Subyek penelitian adalah peserta didik kelas X Teknik Surveying SMK Negeri 3 Gorontalo berjumlah 37 orang dengan jumlah laki-laki 29 orang dan perempuan 8 orang Penelitian ini merupakan Penelitian Tindakan Kelas (PTK) yang dirancang dalam 2 (dua) siklus, dimana tiap siklusnya meliputi empat tahapan yaitu (1) tahap perencanaan, (2) tahap pelaksanan, (3) tahap observasi dan (4) tahap ferleksi.

Sumber data dalam penelitian ini adalah peserta didik kelas XI Teknik Surveying SMK Negeri 3 Gorontalo yang menjadi obyek tindakan serta guru sebagai pelaku tindakan. Jenis data yang digunakan adalah data kuantitatif dan kualitatif yang 
terdiri atas hasil Observasi partisipasi peserta didik dalam proses pembelajaran, Rencana Pelaksanaan Pembelajaran yang disusun guru, hasil kerja peserta didik, daya serap peserta didik. Pengambilan data dilakukan dengan melihat data situasi proses pembelajara, data hasil belajar yang diperoleh peserta didik setelah diberikan angket, dan data tentang refleksi diri serta perubahan yang terjadi di ruang kelas pada saat proses tindakan berlangsung.

\section{HASIL PENELITIAN}

\section{SIKLUS I}

Setelah dilakukan tindakan pada siklus I diperoleh hasil berikut :

1) Hasil Belajar peserta didik

Jumlah peserta didik yang hadir 37 orang, dari jumlah tersebut peserta didik yang memperoleh nilai minimal 7,5 adalah 22 orang peserta didik $(59,46 \%)$ dan yang mencapai nilai kurang dari 7,5 masih 15 peserta didik (40,54\%), dengan nilai rata-rata 7,54 . Untuk lebih jelasnya analisis data tersebut dapat diuraikan dalam tabel berikut :

Analisis Data Hasil Belajar Peserta Didik

\begin{tabular}{|c|c|c|c|c|c|c|}
\hline \multirow{3}{*}{ NO } & \multirow{3}{*}{ Siklus } & \multicolumn{4}{|c|}{$\begin{array}{l}\text { Nilai } \\
\end{array}$} & \multirow{3}{*}{ Daya Serap } \\
\hline & & \multicolumn{2}{|c|}{$\geq 7,5$} & \multicolumn{2}{|c|}{$<7,5$} & \\
\hline & & Jumlah & $\%$ & Jumlah & $\%$ & \\
\hline 1 & I & 22 Siswa & $59.46 \quad \%$ & 15 Siswa & $40.54 \%$ & $75.54 \%$ \\
\hline
\end{tabular}

2) Daya serap peserta didik mencapai 75,54\%,

3) Kualifikasi pembelajaran

a). Aktifitas Guru

Sesuai dengan hasil observasi diperoleh data bahwa aktifitas guru yang paling dominan pada siklus I adalah menjelaskan materi yang sulit, membimbing dan mengamati peserta didik dalam menemukan konsep yaitu $18,33 \%$ dan 18,33\%. Aktifitas lain yang persentasenya cukup besar adalah memberi umpan balik/evaluasi/tanya jawab, menjelaskan materi yang sulit dan membimbing peserta didik merangkum pelajaran yaitu masing-masing sebesar $13,33 \%$ dan $10,00 \%$ dan $10,00 \%$. Analisis data tersebut dapat disajikan dalam tabel sebagai berikut:

Analisis Data Aktifitas Guru dalam Proses Pembelajaran

\begin{tabular}{|l|l|c|}
\hline No & Aktifitas guru yang diamati & \% \\
\hline 1 & Menyampaikan tujuan & 3,33 \\
\hline 2 & $\begin{array}{l}\text { Memotivasi } \\
\text { siswa/merumuskan masalah }\end{array}$ & 10,00 \\
\hline 3 & $\begin{array}{l}\text { Mengkaitkan dengan } \\
\text { pelajaran berikutnya }\end{array}$ & 6,67 \\
\hline 4 & $\begin{array}{l}\text { Menyampaikan } \\
\text { materi/langkah- } \\
\text { langkah/strategi }\end{array}$ & 11,67 \\
\hline 5 & Menjelaskan materi yang sulit & 18,33 \\
\hline 6 & $\begin{array}{l}\text { Membimbing dan mengamati } \\
\text { siswa dalam menemukan } \\
\text { konsep }\end{array}$ & 15,01 \\
\hline 7 & $\begin{array}{l}\text { Meminta siswa menyajikan } \\
\text { dan mendiskusikan hasil } \\
\text { kegiatan }\end{array}$ & 8,33 \\
\hline 8 & Memberikan umpan balik & 18,33 \\
\hline 9 & $\begin{array}{l}\text { Membimbing peserta didik } \\
\text { merangkum pelajaran }\end{array}$ & 8,33 \\
\hline & \multicolumn{2}{|c|}{ Jumlah } \\
\hline
\end{tabular}

b). Aktifitas peserta didik

Data hasil observasi menunjukkan bahwa aktifitas peserta didik

yang mengikuti proses pembelajaran adalah dari 37 peserta didik terdapat 21 peserta didik ( $56,76 \%$ ) yang termasuk sangat aktif dan aktif serta 16 peserta didik ( 43,24\% ) termasuk dalam kategori tidak aktif dan kurang aktif.

Analisis Data Aktifitas Peserta Didik dalam Proses Pembelajasran 


\begin{tabular}{|c|c|c|c|c|c|c|}
\hline No. & Siklus & $\begin{array}{c}\text { Sangat } \\
\text { Aktif }\end{array}$ & Aktif & $\begin{array}{c}\text { Kurang } \\
\text { Aktif }\end{array}$ & Tidak Aktif & Jumlah \\
\hline \hline \multirow{2}{*}{1} & 1 & 11 Siswa & 10 Siswa & 6 Siswa & 10 Siswa & 37 Siswa \\
\hdashline & & $29.73 \%$ & $27.03 \%$ & $16.22 \%$ & 27.03 & $100 \%$ \\
\hline
\end{tabular}

Keterangan

A Sangat Aktif dan Aktif

Siklus I $=29,73 \%+27,03 \%=56,76 \%$

B Kurang Aktif dan Tidak Aktif

Siklus I $=16,22 \%+27,03 \%=43,24 \%$

\section{SIKLUS II}

Setelah dilakukan tindakan pada siklus II dapat diperoleh :

1) Hasil Belajar peserta didik

Jumlah peserta didik yang hadir 37 orang, dari jumlah tersebut peserta didik yang memperoleh nilai minimal 7,5 adalah 35 orang peserta didik $(94.59 \%)$ dan yang mencapai nilai kurang dari 7,5 masih 2 orang peserta didik $(5.41 \%)$. Untuk lebih jelasnya analisis data tersebut dapat diuraikan dalam tabel sebagai berikut :

Analisis Data Hasil Belajar peserta didik

\begin{tabular}{|c|c|c|c|c|c|c|}
\hline \multirow{3}{*}{ NO } & \multirow{3}{*}{ Siklus } & \multicolumn{4}{|c|}{ Nilai } & \multirow{3}{*}{ Daya Serap } \\
\hline & & \multicolumn{2}{|c|}{$\geq 7,5$. } & \multicolumn{2}{|c|}{$<7,5$} & \\
\hline & & Jumlah & $\%$ & Jumlah & $\%$ & \\
\hline 1 & ॥ & 35 Siswa & $94.59 \%$ & 2 Siswa & $5.41 \%$ & $81.49 \%$ \\
\hline
\end{tabular}

2) Daya serap peserta didik mencapai $81,49 \%$,

3) Kualifikasi pembelajaran

a). Aktifitas Guru

Sesuai dengan hasil observasi diperoleh data bahwa aktifitas guru yang paling dominan pada siklus I adalah menjelaskan materi yang sulit, membimbing dan mengamati peserta didik dalam menemukan konsep yaitu $20,00 \%$ dan $18,33 \%$. Aktifitas lain yang persentasenya cukup besar adalah memberi umpan balik/evaluasi/tanya jawab, menjelaskan materi yang sulit dan membimbing peserta didik merangkum pelajaran yitu masing-masing sebesar $13,33 \%$ dan $10,00 \%$. Analisis data tersebut dapat disajikan dalam tabel sebagai berikut:

\section{Analisis Data Aktifitas Guru dalam Proses Pembelajaran}

\begin{tabular}{|c|l|c|}
\hline No & \multicolumn{1}{|c|}{ Aktifitas guru yang diamati } & Persentase \\
\hline 1 & Menyampaikan tujuan & 6,67 \\
\hline 2 & $\begin{array}{l}\text { Memotivasi siswa/merumuskan } \\
\text { masalah }\end{array}$ & 6,67 \\
\hline 3 & $\begin{array}{l}\text { Mengkaitkan dengan pelajaran } \\
\text { berikutnya }\end{array}$ & 6,67 \\
\hline 4 & $\begin{array}{l}\text { Menyampaikan materi, langkah- } \\
\text { langkah, strategi }\end{array}$ & 8,33 \\
\hline 5 & Menjelaskan materi yang sulit & 20,00 \\
\hline 6 & $\begin{array}{l}\text { Membimbing dan mengamati siswa } \\
\text { dalam menemukan konsep }\end{array}$ & 18,33 \\
\hline 7 & $\begin{array}{l}\text { Meminta peserta didik menyajikan } \\
\text { dan mendiskusikan hasil kegiatan }\end{array}$ & 10,00 \\
\hline 8 & Memberikan umpan balik & 13,33 \\
\hline 9 & $\begin{array}{l}\text { Membimbing peserta didik } \\
\text { merangkum pelajaran }\end{array}$ & 10,00 \\
\hline \multicolumn{2}{|c|}{ J u m l a h } & 100 \\
\hline
\end{tabular}

b). Aktifitas peserta didik Data hasil observasi menunjukkan bahwa aktifitas peserta didik yang mengikuti proses pemelajaran adalah dari 37 peserta didik terdapat 29 peserta didik ( $78,38 \%$ ) yang termasuk sangat aktif dan aktif serta 8 peserta didik ( $21,62 \%$ ) termasuk dalam kategori tidak aktif dan kurang aktif.

\section{Analisis Data Aktifitas Guru dalam Proses Pembelajaran}




\begin{tabular}{|c|c|c|c|c|c|}
\hline \multirow[b]{2}{*}{ No. } & \multirow[b]{2}{*}{ Siklus } & \multicolumn{4}{|c|}{ Aktifitas Siswa } \\
\hline & & $\begin{array}{c}\text { Sangat } \\
\text { Aktif }\end{array}$ & Aktif & $\begin{array}{c}\text { Kurang } \\
\text { Aktif }\end{array}$ & Tidak \\
\hline \multirow{2}{*}{1} & \multirow{2}{*}{ II } & 17 Siswa & 12 Siswa & 5 Siswa & $3 \mathrm{Sis}$ \\
\hline & & $45,95 \%$ & $32,43 \%$ & $13,51 \%$ & 8,11 \\
\hline \multicolumn{6}{|c|}{ Keterangan } \\
\hline \multirow[t]{2}{*}{ A } & \multicolumn{5}{|c|}{ Sangat Aktif dan Aktif } \\
\hline & Siklus II & $=$ & $45,95 \%$ & 32,43 & $\%$ \\
\hline \multirow[t]{2}{*}{ B } & \multicolumn{5}{|c|}{ Kurang Aktif dan Tidak Aktif } \\
\hline & Siklus II & $=$ & $13,51 \%$ & 8,11 & $\%$ \\
\hline
\end{tabular}

\section{Pemanfaatan Media}

Seluruh peserta didik sangat tertarik dengan adanya penyampaian materi pelajaran dengan memanfaatkan atau menggunakan media pembelajaran. Hal ini dapat dilihat dari jawaban peserta didik bahwa semua peserta didik

$100 \%$ ) menyatakan atau menjawab menyenangkan, apabila dalam pelaksanaan pembelajaran menggunakan media pembelajaran, tidak ada peserta didik yang menyatakan biasa-biasa saja atau membosankan dalam menerima materi pelajaran dengan memanfaatkan media pembelajarandengan mudah sebanyak 33 peserta didik ( $89.19 \%$ ), yang menyatakan menerima pelajaran dengan biasa-biasa saja sebanyak 4 peserta didik ( $10.81 \%)$ dan yang menyatakan menerima pelajaran menjadi lebih sukar tidak ada.

Kemampuan peserta didik dalam menerima pelajaran setelah guru menggunakan media pembelajaran maka peserta didik yang menyatakan menjadi lebih baik sebanyak 37 peserta didik ( $100 \%$ ), yang menyatakan biasa-biasa saja dan menyatakan tidak ada pengaruhnya tidak ada, di dalam mengikuti peliajaran menyatakan menjadi lebih akdif Jeeblakyak 32 peserta didik ( $86.49 \%$ ) yang menyatakan tidak menghimaiskan sebanyak 2 peserta didik $(-5: 41-9 \%)$ dan yang menyatakan \%ám saja dăam menerima pelajaran 3 peserta didik $(8,11 \%)$.

Dalam merespon materi dengan adanya penggunaan media pronj\&elajaran sangat termotivasi yang menyatakan sangat termotivasi séb. ब19y al\% 28 peserta didik $(75,68 \%)$ dan peserta didik yang menyatakan menerima pelajaran dengan jawaban biasa-biasa saja sebanyak 5 peserta didik $(13,51 \%)$ sedangkan yang tidak termotivasi 4 peserta didik $(10,81 \%)$.

Tingkat kepahaman dalam menerima materi pelajaran peserta didik yang menyatakan paham 31 peserta didik $(83,78 \%)$, yang menyatakan sedikit paham 6 peserta didik $(16,22 \%)$ dan tidak paham tidak ada. Tingkat kejenuhan peserta didik dalam menerima materi pelajaran tidak ada, sebagaimana diketahui peserta didik yang menyatakan merasa bosan 4 peserta didik $(10,81 \%)$ dan yang menyatakan biasa-biasa saja tidak ada, tetapi yang menyatakan tidak merasa bosan sebanyak $33(89,19 \%)$.

Tingkat kesungguhan peserta didik dalam memperhatikan materi pelajaran yang disampaikan dengan media pembelajaran sangat besar. Hal ini dapat dilihat bahwa peserta didik yang menyatakan sangat memperhatikan materi pelajaran sebanyak 28 peserta didik $(75,68 \%)$, yang menyatakan biasa-biasa saja sebanyak 6 peserta didik $(16,22 \%)$ dan yang menyatakan tidak memperhatikan 3 peserta didik $(8,11 \%)$. dalam meningkatkan prestasi belajar siswa yang menyatakan nilainya menjadi lebih bagus sebanyak 29 peserta didik $(78,38 \%)$, yang menyatakan nilainya sedang-sedang saja 8 peserta didik $(21,62$ 
$\%)$ dan yang menyatakan nilainya menurun tidak ada.

\section{KESIMPULAN}

1. Pembelajaran Bahasa Inggris pada materi Pronoun dengan media komputer perangkat lunak Power Point lebih memungkinkan untuk dapat berlangsung dengan tertib dan lancer

2. Peserta didik lebih memberikan respon positif terhadap pembelajaran Bahasa Inggris pada materi Pronoun dengan media komputer dari pada secara konvensional

3. Hasil belajar peserta didik kelas X Teknik Surveying di SMK Negeri 3 Gorontalo pada mata pelajaran Bahasa Inggris materi Pronoun dengan media komputer lebih baik jika dibandingkan dengan metode konvensional

4. Pembelajaran Bahasa Inggris pada materi Pronoun dengan media komputer perangkat lunak Power Point terkendala oleh kesiapan sarana dan kompetensi guru

\section{REFERENCE}

Depdiknas. (2003). Standart Kompetensi Kurikulum 2004, jakarta Depdiknas, 2003, Pedoman Khusus Pengembangan Silabus dan Penilaian Kurikulum 2004, Jakarta

Depdiknas. (2003). Undang-Undang Nomor 20 Sisdiknas, Jakarta

Deny Setaiawan. (2003) Komputer dan Media Pembelajaran ,Jakarta

Sadiman, Arif, dkk. (1993) Media Pendidikan, PT.Raja Gratmido Persada, Jakarta

Sudjana, Nana dan Ahmad Rivai. (1989). Media Pengajaran, Penerbit Sinar Baru, Bandung

Oemar Hamalik. (1989). Komputerisasi Pendidikan Nasional, Mandar Maju, Bandung

Fakultas Keguruan dan Imu Pendidikan

Universitas Bosowa Makassar
M. Subana, Sudrajat .(2005). Dasar-dasar Penelitian Ilmiah, Penerbit Pustaka Setia, Bandung 